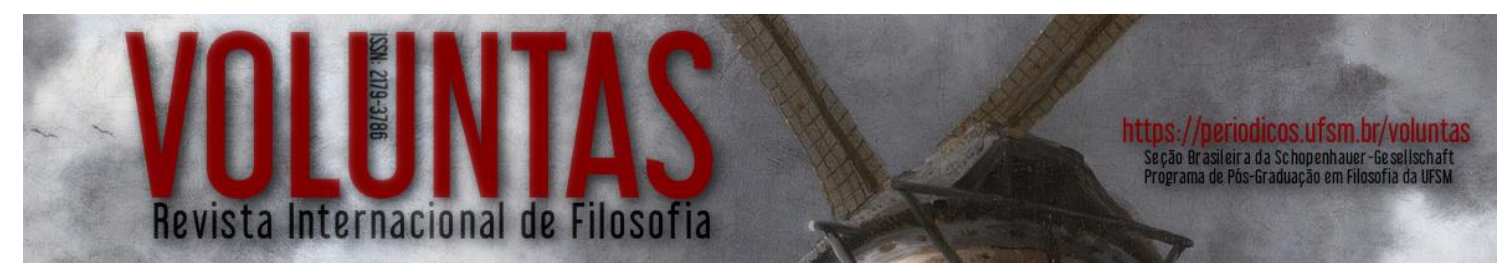

ISSN: 2179-3786

DOI: $10.5902 / 2179378635580$

\title{
Apresentação e tradução de "O objetivo de toda a vida é a morte" - Schopenhauer e o instinto de morte de Freud, de Marcel Zentner
}

\author{
Presentation and translation of "The aim of all life is death" - Schopenhauer and the death \\ instinct of Freud", by Marcel Zentner
}

\author{
Tradução de \\ Guilherme Marconi Germer \\ Pós-Doutorando em Filosofia pela Universidade de São Paulo (USP) \\ E-mail: guilhermeguita@gmail.com
}

Resumo: O que se segue é uma apresentação e a tradução de „Das Ziel alles Lebens ist der Tod”Schopenhauer und Freuds Todestrieb, de Marcel Zentner (Zürich), publicado em: RAINER, Specht (Org.). Archiv für Geschichte der Pbilosophie. Berlin: Walter de Gruyter, 1993, vol. 75, p. 319-340. Trata-se de um detalhamento dos problemas que envolvem o topos criado por Freud de que, com seu dualismo dos instintos de vida e de morte, exposto em Além do princípio de prazer (1920), "desaguara no porto da filosofia de Schopenhauer". As diferenças fundamentais desse dualismo em relação à dicotomia schopenhaueriana da afirmação e da negação da Vontade merecem um esclarecimento pormenorizado, defende Zentner, para que não se perca de vista o fato de que a principal antecipação schopenhaueriana de Freud concerne, antes, ao complexo conceitual articulado em torno à primeira teoria dos instintos, a teoria da repressão e o "modelo estrutural da psique".

Palavras-chave: Dualismo; Monismo; Pessimismo; Escola de Schopenhauer; Metapsicologia.

Abstract: What follows is a presentation and translation of „Das Ziel alles Lebens ist der Tod”Schopenhauer und Freuds Todestrieb, by Marcel Zentner (Zürich), published in: RAINER, Specht (Org.). Archiv für Geschichte der Philosophie. Berlin: Walter de Gruyter, 1993, Vol. 75, p. 319 - 340. It is an analysis of the problems involving the topos created by Freud, according to which his dualism of the instincts of life and death, set forth in Beyond the Principle of Pleasure (1920), brought him to "the port of Schopenhauer's philosophy". The fundamental differences of this dualism with the Schopenhauerian dichotomy of the affirmation and negation of the will deserve a detailed clarification, says Zentner, so as not to lose sight of the fact that Schopenhauer's main anticipation of Freud concerns the conceptual complex articulated around the first theory of the instincts, the theory of repression and the "structural model of the psyche".

Key-words: Dualism; Monism; Pessimism; Schopenhauer's school; Metapsychology.

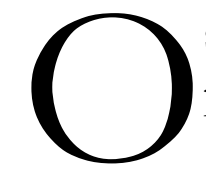

swaldo Giacoia Júnior tem razão quando escreve que "o dualismo entre as pulsões” - ou os instintos (Triebe), como prefere Paulo César de Souza ${ }^{1}$ - de

\footnotetext{
${ }^{1}$ No que atina à difícil tradução de Trieb ao português, concordamos com a oposição de Pedro Heliodoro Tavares ao "exagero daqueles que separam radicalmente as acepções de instinto e pulsão" (TAVARES, As novas traducões de Freud feitas diretamente do alemão: estilo e terminologia, p. 122). A rigor, ambos os termos são adequados
} 
vida e de morte, exposto por Sigmund Freud em Além do princípio do prazer (1920), "pode ser caracterizado como a base ontológica da metapsicologia e, por conseguinte, de toda a infra-estrutura teórica da psicanálise" 2 . Por outro lado, Luiz Roberto Monzani não está menos certo quando adverte que Além do princípio do prazeré um dos textos mais "desorientadores" e "cheios de armadilhas"3 da história da psicanálise. Diante de semelhante importância e complexidade, toda luz que possa ser conquistada nos labirintos conceituais desse texto é de enorme valor. Nessa tarefa, a consulta do comentário especializado é imprescindível: autores como Marcel Zentner, Günter Gödde, Paul-Laurent Assoun, e etc., nos ajudam, de modo indispensável, a desemaranhar certas complicações que possam resultar da leitura desse texto tão denso, e evitar posicionamentos unilaterais, insipientes ou problemáticos. Entre os mais comuns erros de interpretação desse clássico está a defesa de que o dualismo freudiano dos instintos de vida e de morte possui uma "dependência"4 clara e direta

\footnotetext{
para essa tradução, embora apresentem limitações: "instinto", de fato, se corresponde mais diretamente com "Instinkt", do alemão, e segundo Hanns, tem um sentido "mais estreito que Trieb", levando "a uma compreensão mais desligada dos aspectos volitivos e representacionais também presentes em Trieb” (HANNS, Dicionário Comentado do Alemão de Freud, p. 339). Por isso, muitos tradutores se alinham à tradição francesa de verter "Trieb" por "pulsão" ("pulsion", em francês). Aderiremos, aqui, porém, à escolha de Paulo César de Souza por "instinto": em primeiro lugar, porque há um grande interesse na padronização dos vocábulos técnicos freudianos em português, e a premiada e competente tradução de Souza se presta para tanto. Além disso, a tradução de "Trieb" por "instinto", inspirada na preferência inglesa de Strachey por "instinct" e não "drive", se justifica pelo fato de "pulsão" já se afastar da base biológica e orgânica que Freud associou ao conceito de "Trieb". Longe de reduzi-lo a essa base, Freud sempre enfatizou à correspondência entre as vivências psíquicas e as corporais, e chegou mesmo a empregar a expressão "organischen Triebe" (FREUD, Jenseits des Lustprinzips, p. 39) como sinônimo de "Trieb". Souza argumenta ainda com base na etimologia da palavra "instinto", que assim como "Trieb" de Freud, denota o que "instiga, aguilhoa, estimula" (SOUZA, As Palavras de Freud-O Vocabulário Freudiano e suas Versões, p. 31, 266). Uma vez que o tradutor reconhece que sua opção não é "definitiva” ou "absoluta” (SOUZA, Esta edição, p. 12), mas pode ser substituída por "pulsão" sem grandes problemas, ele se sente à vontade para justificar-se, inclusive, com o recurso ao humor: ao perguntar a um amigo qual das duas opções preferia, conta que esse lhe respondeu: "Pulsão têm os anjos (...) gente tem instinto" (SOUZA, As Palavras de Freud - O Vocabulário Freudiano e suas Versões, p. 252, 266).

${ }^{2}$ GIACOIA JR., Além do princípio do prazer: um dualismo incontornável, p. 23.

${ }^{3}$ MONZANI, Freud: O movimento de um Pensamento, p. 146.

4 Para dar apenas um exemplo de comentador que fez uso explícito dessa expressão, e mesmo após a leitura da crítica de Zentner a essa aproximação, Stephen Artzer se opôs nominalmente ao último e defendeu a existência de "dependências" (Abhangigkeinten. ATZERT, Zwei Aufsätze über Leben und Tod: Sigmund Freuds Jenseits des Lustprinzip und Arthur Schopenhauers Transscendente Spekulation über die anscheinende Absichtlichkeit im Schicksal des Einzelnen, p. 193) entre o dualismo tardio dos instintos de Freud e a metafísica dos costumes de Schopenhauer. Conforme Artzer, é "evidente a aproximação conceitual entre o modelo de significação de Freud" (Idem, p. 190), desenvolvido em Além do princípio do prazer, e a Especulação Transcendente Sobre os Tons de Intencionalidade no Destino dos Indivíduos, de Schopenhauer. Em ambos os textos, esses autores exploram a manifestação de um "destino" de origem aparentemente externa, mas que, na realidade, provém de escolhas inconscientes dos indivíduos, que se encaminham, por si sós, a direções dolorosas, anti-eróticas ou mortuárias, e às quais ambos os autores associaram termos teleológicos, como alvo (Ziel) ou objetivo (Zweck) da vida. Embora Artzer tenha acentuado essa proximidade e herança, que de fato, existe entre Schopenhauer e Freud, ele também reconheceu que o fim ético ao qual a Vontade schopenhaueriana se conduz a si própria não é "a morte, como Freud lhe atribui equivocadamente, mas a renúncia interna da Vontade, promovida diante da morte" (Idem, p. 188). Por essa distinção, o argumento de Artzer da "conexão estrutural, evidentemente clara, entre ambos os textos" (Idem p. 185) não entra em contradição com o destaque de Zentner, aqui desenvolvido, das diferenças essenciais entre o dualismo instintivo tardio de Freud e o monismo da Vontade de Schopenhauer, mas pode ser entendido como uma espécie de complemento subsequente.
}

Voluntas: Revista Internacional de Filosofia - periodicos.ufsm.br/voluntas - Santa Maria - Vol. 9, n. 2, jul.-dez. 2018, p. 151-179. 
da filosofia prática schopenhaueriana (grosso modo, sua psicologia, ética e metafísica dos costumes), ou mais particularmente, de sua polaridade da afirmação e negação da Vontade de viver. O próprio Freud foi quem deu origem a essa "lenda", quando comparou seu dualismo tardio dos instintos à dicotomia que entende haver em Schopenhauer entre a morte e Eros. Muitos comentadores aderiram a esse "tópos" e encontraram na frase "o alvo (Ziel) de toda a vida é a morte"5 um sentido praticamente idêntico à sentença de Schopenhauer "o fim (Zweck) da vida é a morte” (P I, p. 236). Conforme Zentner, porém, as diferenças dos contextos de ambas as locuções, ou mais amplamente, entre o dualismo instintivo tardio de Freud e o monismo da Vontade de Schopenhauer, preponderam sobre as semelhanças, de modo que o destaque da proximidade dessas concepções é não somente problemático, como nos faz perder de vista as principais antecipações schopenhauerianas da metapsicologia freudiana.

No pano de fundo dessa discussão está o problema da fortuna da filosofia prática schopenhaueriana. Concordamos com Zentner em que o núcleo da antecipação schopenhaueriana de Freud se encontra, antes, no complexo conceitual que envolve o primeiro dualismo instintivo freudiano (instintos de sexualidade e de auto-conservação), a teoria da repressão e o seu "modelo estrutural da psique" (sua topologia). Assim, se em seu célebre Die Flucht ins Vergessen: die Anfänge der Psychoanalyse Freuds bei Schopenhauer (A evasão no esquecimento: as origens da psicanálise de Freud em Schopenhauer, 1995), Zentner detalhou as previsões fundamentais de Schopenhauer da metapsicologia freudiana ${ }^{6}$, atinentes a esse complexo, no presente artigo, o autor aclara as distâncias essenciais entre o dualismo instintivo tardio de Freud e a filosofia de Schopenhauer. Uma vez que a crítica aqui desenvolvida pressupõe a familiaridade com Além do princípio do prazer, apresentaremos, na sequência, um breve resumo dos sete capítulos do livro:

1 - O problema: a regulação automática do curso dos processos psíquicos pelo princípio do prazer (que determina a busca do prazer e a fuga do desprazer, entendidos, respectivamente, como a diminuição e o aumento da "quantidade de excitação [...] existente na vida psíquica"7) é posta em xeque. 2 e 3 - Os fenômenos que pressupõem uma operação anterior ao princípio do prazer são: os sonhos de neurose traumática, as repetições infantis de eventos desagradáveis, as neuroses de transferência e o "eterno retorno" de certos indivíduos a uma mesma frustração. 4 A operação que sobrepuja o princípio do prazer é a da ligação (Bindung) da energia

\footnotetext{
${ }^{5}$ FREUD, Neue Folge der Vorlesungen zur Einführung in die Psychoanalyse, p. 40.

${ }^{6}$ Com esse aprofundamento, Zentner se insere no grupo de comentadores que sustentam a inserção de Freud, pelo menos, na proximidade da escola de Schopenhauer. Para outras posições semelhantes, cf. HORKHEIMER, Das Schlimme erwarten und doch das Gute tun, p. 442. GÖDDE, Schopenhauers Entdeckung der Psychologie des Unbewussten. LÜTKEHAUS, Schopenhauers und Freuds „Dritte Kränkung": Eine Verdrängungsgeschichte?. YOUNG e BROOK, Schopenhaner and Freud. ASSOUN, Frend: a Filosofia e os Filósofos, p. 198.

${ }^{7}$ FREUD, Além do princípio do prazer, p. 163.
} 
livre e "invasora" do aparelho psíquico, de modo semelhante ao que ocorre na inundação de energia no mesmo no caso do traumatismo externo (nesse último caso, a inundação tem uma origem externa, o que, assim como quando possui uma origem interna e instintiva, coloca ao aparelho psíquico a necessidade de "ligação" dessa energia, antes de que se possa escoá-la conforme o princípio do prazer). Essa operação anterior de ligação (Bindung) é facilitada pela compulsão à repetição, que visa a criar um estado mais elevado de catexização no interior do aparelho psíquico, o que lhe dá melhores condições de ligação da energia "invasora". Essa conclusão tem por premissa a hipótese de que quanto maior for a catexização do aparelho, maior será sua capacidade de ligação, o que é fundamentado pela observação das neuroses de guerra, em que o susto (condicionado pelo baixo nível de catexização) e a ausência de ferimento são fundamentais ao desenvolvimento dessa psicopatologia. 5 Remodelação da teoria topológica, econômica e, sobretudo, dinâmica da psique à luz da especulação anterior: a compulsão à repetição é impulsiva (triebhaft), e quando contrária ao princípio do prazer, aparentemente "demoníaca (...) Um instinto seria um impulso [orgânico] tendente à restauração de um estado anterior, que esse ser vivo

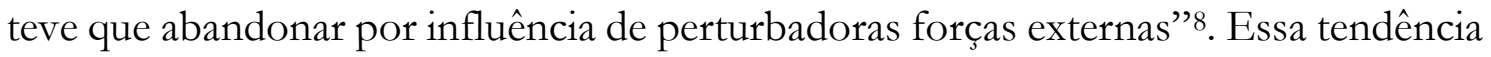
à repetição é predominante nos instintos sexuais (que há muito já foram reconhecidos como fundamentais), o que se constata, por exemplo, no comportamento de muitos animais de retornarem a antigos locais de habitação, para se reproduzirem ou ovularem, "nos fenômenos da hereditariedade e nos fatos da embriologia" . Se, porém, morremos por causas naturais e internas, ao lado dos instintos sexuais também se encontram os instintos fundamentais de morte, que visam a reconduzir o organismo a um estado inorgânico de não excitação e paz, anterior à vida e semelhante à morte. 6 - Não refutação da biologia e da filosofia desse novo dualismo, e seu endossamento por parte de experimentos e conclusões de Woodruff, Weissmann e Hering, e (parcialmente) da intuição metafísica de Platão e Schopenhauer. 7 Conclusão: "O princípio de prazer é uma tendência que se acha a serviço de uma função, à qual cabe tornar o aparelho psíquico isento de excitação, ou conservar o montante de excitação dentro dele constante ou o menor possível"10. A ligação (Bindung) participa dessa função ao substituir o processo primário pelo secundário, o que "introduz e assegura o domínio do princípio do prazer"11. A função primária do aparelho psíquico põe o princípio do prazer "a serviço dos instintos de morte" 12 , que "trabalham discretamente", enquanto Eros perturba a paz com "tensões cuja eliminação é sentida como prazer"13.

\footnotetext{
${ }^{8}$ Idem, p. 201 e 202.

${ }^{9}$ Ibidem.

${ }^{10}$ Idem, p. 236.

11 Ibidem.

${ }^{12}$ Idem, p. 238.

13 Ibidem.
} 
Como se nota, embora a referência de Freud a Schopenhauer, nesse texto, tenha a sua importância na argumentação desenvolvida, ela está longe de ser decisiva, o que já nos alerta quanto ao exagero de se falar em uma "dependência” do dualismo freudiano da filosofia prática schopenhaueriana. Além disso, Zentner pontuará, na sequência, uma série de diferenças entre as concepções de ambos os autores sobre esse tema e que não foram reconhecidas por Freud e pelos comentadores adeptos de sua aproximação de Schopenhauer. Por fim, se robustece ainda mais a crítica de Zentner à interpretação falha de Freud e seus comentadores a indicação de que o que foi, talvez, a fonte principal de influência sobre essa teoria tardia dos instintos foi muito distante de Schopenhauer, a saber: a Escola Médica de Helmholtz. Como se sabe, o cientista que ficou conhecido como o "embaixador no extremo oriente"14 dessa tradição foi o professor de fisiologia de Freud, Ernst Brücke, que Freud afirmou ter sido a "maior autoridade que já teve influência sobre ele"15. Em uma carta de seu colaborador Du Bois-Reymond, citada por Ernst Jones, se vê que ambos os positivistas compartilharam um projeto de reducionismo dos fenômenos orgânicos a um dualismo das forças de atração e repulsão da matéria, que guardava semelhanças fundamentais com o dualismo tardio dos instintos de Freud. A diferença entre ambos os reducionismos esteve apenas no fato de que, enquanto o dualismo dos positivistas era mecanicista, o de Freud, era vitalista ${ }^{16}$ (embora abrigasse elementos mecanicistas, subordinadamente). Com as seguintes palavras, Du Bois-Reymond resumiu o intento reducionista de sua escola científica:

Em 1892 escrevia Du Bois-Reymond: "Brücke e eu fizemos o solene juramento de dar vigor a essa verdade: Não existem no organismo outras forças ativas que não as forças físicas e químicas correntes. Naqueles casos em que, por um momento, não podem ser explicados por essas forças, deve-se buscar encontrar a forma ou a via específica da ação das últimas, mediante o método físico-matemático, ou então supor a existência de novas forças, iguais em dignidade às forças químicas inerentes à matéria, $\mathrm{e}$ reduzivivis às forças de atração e repulsão"17.

O jovem Freud procurou seguir à risca o projeto mecanicista de Brücke, e com esse intento, elaborou o inédito Projeto de uma psicologia científica $(1985)^{18}$. Contudo, ele não conseguiu levar essa proposta adiante, e teve que se vincular, já no texto citado,

\footnotetext{
${ }^{14}$ JONES, Vida y Obra de Sigmund Freud, p. 64.

${ }^{15}$ FREUD, Nachwort zur „Frage der Laienanalyse", p. 290.

${ }^{16}$ Segundo Franz Mockrauer, o vitalismo e o mecanicismo foram duas tendências filosóficas muito expressivas nos séculos XIX e XX, e que podem ser definidas, respectivamente, pela adoção ou rejeição de (pelo menos) um "princípio natural e fundamental na explicação, particularmente, dos fenômenos vitais (....) princípio relacionado às formas e ideias” (MOCKRAUER, Schopenhauers Stellung in der Philosophie der Gegenwart, p. 28-29). ${ }^{17}$ JONES, Vida y Obra de Sigmund Freud, p. 64. Grifo nosso.

${ }^{18}$ Como evidência do intuito mecanicista desse texto, pode ser citada a afirmação introdutória de Freud de que buscaria, nele, "prover uma psicologia que fosse ciência natural: isto é, representar os processos psíquicos como estados quantitativamente determinados de partículas materiais especificáveis” (FREUD, Projeto para uma psicologia cientifica, p. 347).
} 
à tendência oposta do vitalismo ${ }^{19}$. Posteriormente, Freud elaborou uma série de teorias vitalistas dos instintos, que serão caracterizadas por Zentner na sequência, e que sempre foram dualistas. No cume desses dualismos, se encontra a teoria dos instintos de vida e de morte aqui tematizada, e a qual não deixou de ser uma curiosa inversão e "biologização" da polaridade positivista das forças físicas de atração (gravidade) e repulsão (resistência, impenetrabilidade) da matéria. Afinal, o que são os instintos de vida ou Eros de Freud, senão uma força fundamental de atratividade dos seres vivos? Nas palavras de Freud: "Os instintos eróticos (...) querem reunir (zusammenbaden) sempre e cada vez mais a substância viva em unidades maiores"20; sua força é "assimiladora e construtiva" 21 . E o que são os instintos de morte freudianos senão algo muito distinto da negação da Vontade de Schopenhauer (que não é um instinto biológico, mas uma negação do instinto), e muito mais semelhante à força física da repulsão da matéria, com a diferença de agir apenas nos organismos vivos? Nos termos de Freud: "Os instintos de morte (...) se opõem ao esforço de Eros e reconduzem o ser vivo ao estado inorgânico"22; sua força é "destrutiva e dissimiladora"23.

Que Freud nunca tenha reconhecido essa inspiração positivista de seu dualismo tardio dos instintos, e tenha destacado, em suas raízes, uma teoria muito menos familiar à mesma, como a do monismo da Vontade de Schopenhauer, será explicado por Zentner com base na hipótese de que Freud foi um estrategista de citações, isto é, um autor que nunca utilizou referências de modo neutro e objetivo, mas de maneira subordinada a duas intenções fundamentais: a da salvaguarda de sua originalidade, e a do reforço, quando necessário, de suas teorias polêmicas, com o argumento de autoridade de que elas concordavam com intuições "ousadas" de grandes pensadores. A despeito desse procedimento, concordamos com Zentner em que, na terceira ferida no narcisismo da humanidade, que Freud reconhece compartilhar com Schopenhauer ${ }^{24}$, as teorias topológicas, da repressão e da sexualidade do primeiro, bem como seu ateísmo radical, pessimismo e sua concepção da centralidade da morte na vida psíquica, atestam de modo muito mais claro a fortuna da filosofia prática de Schopenhauer na obra de Freud, do que as forçadas e proliferadas comparações entre seu dualismo instintivo tardio e a dicotomia da negação e afirmação da Vontade de Schopenhauer. No que concerne ao dualismo instintivo tardio freudiano, se alguma previsão de Schopenhauer puder ser indicada,

\footnotetext{
${ }^{19}$ Isso ocorreu, por exemplo, quando Freud escreveu que o mecanismo da repressão pressupunha o postulado de uma "vontade - o derivado das pulsões [instintos, Triebe]" (FREUD, Projeto para uma psicologia cientifica, p. 369).

${ }^{20}$ FREUD, Neue Folge der Vorlesungen zur Einfübrung in die Psychoanalyse, p. 11.

${ }^{21}$ FREUD, Jenseits des Lustprinzips, p. 53.

22 FREUD, Neue Folge der Vorlesungen zur Einführung in die Psychoanalyse, p. 11.

${ }^{23}$ FREUD, Jenseits des Lustprinzips, p. 53.

${ }^{24}$ Cf. FREUD, ABRAHAM, Briefe 1907-1926, carta de 25/3/1917, p. 237.
}

Voluntas: Revista Internacional de Filosofia - periodicos.ufsm.br/voluntas - Santa Maria - Vol. 9, n. 2, jul.-dez. 2018, p. 151-179. 
ela concernirá, prioritariamente, à perspectiva da subordinação do mecanicismo ao vitalismo ${ }^{25}$.

\title{
“O objetivo de toda a vida é a morte" - Schopenhauer e o instinto de morte de Freud
}

\author{
Quanto mais popular uma ideia é, menos se \\ medita sobre ela, e mais importante deve ser, \\ portanto, examinar o seu contorno.
}

Paul Feyerabendt

A hipótese de Freud do instinto de morte é e sempre foi um tema espinhoso (unstriteness). Enquanto a maioria dos estudos examinaram essa hipótese em um nível sistemático ou biográfico, recuou-se a concatenações históricas. Em decorrência disso, se encontra sempre na literatura [de comentário especializado] a reiterada convicção de que essa hipótese descende em primeira linha de Schopenhauer, o qual falou da "morte, esse resultado próprio (eigentlichen Resultat), e neste sentido, fim (Zweck) da vida (P I, 236)". De fato, essa locução relembra a fórmula: "O objetivo (Ziel) de toda [sic] a vida é a morte" (GW 13, 40) ${ }^{26}$, com a qual Freud introduziu sua hipótese do instinto de morte. Freud e seus comentadores partiram, repetidamente, da concepção de que o teor de ambas as citações possui uma concordância interna.

\footnotetext{
${ }^{25}$ Mesmo que essa previsão de Schopenhauer não tenha sido assimilada de modo consciente por Freud, ela foi decisiva à construção das "condições de background que propiciaram o surgimento da psicanálise " (GARDNER, Schopenhauer, Will and the Unconscious, p. 403) - o que, segundo Sebastian Gardner, constitui o núcleo principal da fortuna de Schopenhauer sobre a psicanálise. A seguinte crítica de Schopenhauer à "moda" existente já em seus tempos de redução da força vital (ou Vontade) às forças da física e química antecipou a essência da divergência de Freud ante o mecanicismo da Escola de Helmholz: "Se uma força natural e singular não determina (bewegt), conduz (lenkt), ordena (ordnet) e se apresenta (sich darstellt) no complexo mecanismo (Getriebe) do corpo inteiro, assim como a gravidade aproxima essencialmente os corpos uns dos outros (...) então, a vida é uma falsa aparência, uma ilusão, e na realidade, todo ser vivo não passa de um autômato, um jogo de forças mecânicas, físicas e químicas (...) Sem dúvida, as forças físicas e químicas agem no organismo animal: mas o que o conserva intacto e o conduz, de modo que nele se forma e perdura um organismo conveniente (zweckmäßig), - é a força vital: ela governa, portanto, aquelas forças e molda os seus efeitos, os quais são, por isso, subordinados" (P II, \96, p. 191). O acréscimo de Freud ante o vitalismo de Schopenhauer é o de que há duas forças instintivas fundamentais, e não só uma: a que ordena e tende à restauração de um estado originário do elemento vital (por meio da fusão com novas partículas vitais), e a que desordena e visa ao regresso a um estado originário e mortuário de não excitação, temporalmente anterior à vida ("o não-vivo existiu antes do vivo". FREUD, Jenseits des Lustprinzips, p. 40). Em Schopenhauer, a negação da Vontade de viver não aponta a um estágio precedente, temporalmente, à afirmação, mas se define pelo completo desligamento e auto-supressão do tempo, espaço e causalidade (chamados por ele de principium individuationis, e entendidos como a forma do fenômeno).

${ }^{26}$ Doravante, para se manter o estilo do texto original, Freud será citado a partir do texto de Gesammelten Werke $(\mathrm{GW})$, com os volumes numerados em caracteres românicos, seguidos do número de página.
} 
Não apenas isso: a locução de Schopenhauer da morte como o "resultado próprio, e neste sentido, o fim (Zweck) da vida" foi oposta, por Freud, à "Vontade de vida" do filósofo, com o que Freud acreditou poder reconduzir seu dualismo tardio dos instintos de morte e de vida às concepções de Schopenhauer. Essa correlação, defendida e assimilada também pelos comentadores, recebeu, desde as investigações mais precoces, uma sobrelevação, na medida em que foi postulado que Freud encontrou na obra de Schopenhauer a fonte "mais importante" e "verdadeira" de toda a sua teoria tardia dos instintos. Isso, porém, nunca foi reconhecido abertamente por Freud ${ }^{27}$. Diante da infinitude de comentários desse tipo, pode-se assegurar que a consideração das "amplas coincidências" 28 entre a doutrina instintiva tardia de Freud e as concepções de Schopenhauer se estabeleceu como um tópos da história das ideias. Contudo, devo, aqui, levantar uma objeção contra isso.

Em primeiro lugar (1), serão documentadas as referências postuladas por Freud e seus comentadores entre as considerações de Schopenhauer e a teoria psicanalítica tardia dos instintos. Com isso, será mostrado (2) que a identificação do conteúdo da locução de Freud, "o objetivo (Ziel) de toda vida é a morte", com a expressão da "morte, esse resultado próprio, e neste sentido, fim (Zweck) da vida", parte de uma interpretação falha do filósofo, e que ambas as expressões possuem um significado fundamentalmente distinto. Em terceiro lugar (3), será perguntado se outros "topoi" [convenções] da filosofia de Schopenhauer não poderiam autorizar sua indicação como o precursor da teoria dos instintos tardia de Freud. Em quarto lugar (4), será demonstrado que, contrariamente à interpretação corrente, não foi a tardia, mas a primeira teoria dos instintos de Freud que pode ser estabelecida como descendente de Schopenhauer. Finalmente (5), será examinado, no sentido de uma "teoria do erro" (Irrtumstheorie), as causas da lenda aqui tematizada e de sua continuação.

Em primeiro lugar, o próprio Freud aludiu, expressa e repetidamente, às coincidências entre sua hipótese do instinto de morte, e sobretudo, de sua teoria tardia dos instintos, e a filosofia de Schopenhauer.

Já em Além do princípio do praz̧er29, ele escreve:

Nós nos prolongamos um pouco aqui nessa interpretação dualística e curiosa do instinto de vida. De acordo com a teoria de E. Hering dos fenômenos na substância viva, nela percorre um processo duplo e

\footnotetext{
27 KAISER-EL-SAFTI, Der Nachdenker. Die Entstehung der Metapsychologie Freuds in ibrer Abhängigkeit von Schopenhauer und Nietzsche, p. 195 e ss..

${ }_{28}$ Cf. Nota 24, sobre R. Brun.

${ }^{29}$ Doravante abreviado por APP.
} 
ininterrupto de direções opostas, em que uma é assimiladora e construtiva, e a outra é dissimiladora e destrutiva. Devemos nos atrever a reconhecer nessas duas orientações dos processos vitais a ação de nossos dois movimentos instintivos (Triebregungen), os instintos de vida e os instintos de morte? Nós não podemos, porém, nos encobrir algo a mais: que, de repente, desaguamos no porto da filosofia de Schopenhauer, para quem, de fato $(j a)$, a morte é o 'resultado próprio', e neste sentido, o fim (Zweck) da vida, enquanto que o instinto sexual é a corporificarão da Vontade de viver (GW, XIII, 53).

Nos moldes da exposição posterior e pormenorizada de sua doutrina instintiva tardia na nova série das Lições introdutórias de Psicanálise, Freud retornou uma outra vez a Schopenhauer:

E agora, os instintos em que acreditamos se separam, para nós, em dois grupos: o dos instintos eróticos, que querem reunir (zusammenbaden) sempre e cada vez mais a substância viva em unidades maiores, e os instintos de morte, que se opõem a esse esforço e reconduzem o ser vivo ao estado inorgânico. Da reunião e ação oposta de ambos provêm os fenômenos vivos, aos quais a morte põe um fim. Os senhores podem talvez dizer: isso não é ciência natural, é a filosofia de Schopenhauer. Contudo, por que, minhas damas e cavalheiros, um ousado pensador (kïhner Denker) não pode ter adivinhado o que, depois, um pesquisador de detalhes, sóbrio e laborioso (nüchterne und mühselige Detailforschung), confirmaria? (GW XV, 11).

Como se depreende dessas duas referências textuais, vê-se que Freud se representa um ponto de vista, com sua doutrina tardia dos instintos, que não poderia ser mantido separadamente do de Schopenhauer. A partícula "de fato" ( $j a)$, empregada na passagem [de sua teoria à de Schopenhauer], na última citação de APP, sugere, evidentemente, que na obra de Schopenhauer não apenas se encontram inseridos alguns paralelos (Parallelen) com o modelo instintivo e dualístico dos instintos de morte e de vida, mas também que se poderia pressupor um reconhecimento universal desses paralelos. Esse postulado de concordância parte daquela expressão de Schopenhauer da "morte, esse resultado próprio, e neste sentido, fim (Zweck) da vida”, à qual já fizemos referência no início. Essa expressão de Schopenhauer parece ser tratada por Freud como uma prova de que Schopenhauer já tinha defendido uma concepção comparável à do instinto de morte. Posteriormente, Freud vai além, e opõe à frase citada de Schopenhauer, a "Vontade de viver" do filósofo, e com base nisso, pretende deduzir um dualismo instintivo, analogamente a como ele expôs em seus anos tardios. Um dualismo de Eros e Tânatos, portanto. De instintos de vida e de morte. Schopenhauer, destarte, é indicado não apenas como o precursor da hipótese do instinto de morte, mas da teoria tardia dos instintos por inteira. 
No trecho da nova série de Lições Introdutórias de Psicanálise, Freud vai ainda mais longe. Ele identifica o dualismo dos instintos de vida e de morte com a filosofia de Schopenhauer "tout court" [brevemente], e se priva de indicar uma fonte específica. Surge, com isso, a impressão de que a dicotomia (Dichotomie) dos instintos de vida e de morte corresponde a uma tese fundamental da filosofia de Schopenhauer.

O postulado colocado por Freud das "amplas coincidências" entre sua teoria instintiva tardia e as considerações de Schopenhauer foi assumido por um grande número de comentadores e intérpretes. Por isso, eles negligenciaram, regularmente, à necessidade de indicação de provas que poderiam tornar a conexão assumida compreensível. Entre as indicações correspondentes dos comentadores, deixam-se verificar acentuações distintas: em primeiro lugar, há um grupo de comentadores que, pura e simplesmente, se agarram (festhalten) às coincidências e não apresentam consideração alguma sobre os determinantes desses paralelos ${ }^{30}$. Um segundo grupo, pelo contrário, já é da posição de que Freud recebeu a hipótese do instinto de morte, assim como sua completa teoria tardia do instinto de vida, diretamente de Schopenhauer ${ }^{31}$. Dentro de ambos os grupos existem alguns intérpretes que

$30 \mathrm{O}$ primeiro que pode ter se expressado dessa maneira foi o crítico de literatura americano J. C. Ransom, que falou de "afiliações óbvias" entre a hipótese do instinto de morte de Freud e a filosofia de Schopenhauer (Cf. RANSOM, Freud and Literature, p. 449). Em acentuada concordância com ele, L. S. Granjel escreveu em seu estudo pouco apreciado pelos comentadores de uma "evidente aproximación” entre o dualismo tardio dos instintos de Freud e a determinação de Schopenhauer da relação entre a Vontade de viver e a morte (Cf. GRANJEL, Schopenhauery Freud, p. 120 - 134). Pouco depois, R. Brun se referiu às "vastas coincidências" entre a hipótese de morte de Freud e a filosofia de Schopenhauer (Cf. BRUN, Über Freuds Hypothese vom Todestrieb, p. 85 e ss.). Que a consideração de Freud da morte como o "objetivo de toda a vida" corresponda à posição de Schopenhauer, deixa-se também presumir de E. Jones, quando esse escreve o seguinte: "O impasse apareceu de modo absoluto dessa vez, e Freud aparentou ter aportado na posição de Schopenhauer, que ensinou que 'a morte é o fim da vida"” (Cf. JONES, Sigmund Freud, Life and Work, vol. III, p. 294). Com ainda mais clareza, enuncia C. T. Dimitrov: "É de se salientar que a ideia do instinto de morte, que foi considerada por alguns biógrafos e críticos de Freud como uma visão 'completamente específica' de Freud, não apenas foi esboçada por Schopenhauer, mas foi aprofundada de modo relativamente minucioso pelo filósofo" (Cf. DIMITROV, A. Schopenhauer und S. Freud, p. 73). Da mesma maneira, pertence a esse grupo J. Clegg, que acredita ter descoberto em Schopenhauer um dualista teleológico do tipo do Freud tardio (Cf. CLEGG, Freud and the Issue of Pessimism, p. 39), e F. Nicolino, que anotou que Freud chegou o mais perto de Schopenhauer, entre todas as suas obras, em APP (Cf. NICOLINO, Indagini su Frend e sulla Psicoanalisi, p. 136). Também H. F. Ellenberger e J. Rattner não se excluem desse grupo, na medida em que validam que Freud, "como" (cf. ELLENBERGER, Die Entdeckung des Unbewußten, p. 710) ou "igualmente como" (Cf. RATTNER, Klassiker der Tiefenpsychologie, p. 17) Schopenhauer, formulou a hipótese: "O objetivo da vida é a morte". Dado que o "como", que ambos os autores empregam aqui, não descrimina entre o literal e o significado desse literal, é sugerido que Schopenhauer não apenas utiliza o mesmo teor literal [dessa frase], como que esse é entendido já no sentido de Freud.

${ }^{31}$ Isso entende $W$. Bernhard, a saber, que "as concepções de Schopenhauer exerceram um papel essencial no preparo do instinto de morte". Ele anota ainda que a influência de Schopenhauer sobre a doutrina tardia dos instintos de Freud poder ser "tomada como certa". Faltam referências e provas (Cf. BERNHARD, Schopenhauer und die moderne Charakterologie, p. 118 e ss.). Apesar disso, também se deve mencionar F. Seifert, que "ratifica" a consideração anterior (Cf. SEIFERT, Tiefenpsychologie, p. 88). A. Hübscher é da seguinte concepção: "Em seus escritos tardios, Freud, mais uma vez em imediata afiliação a Schopenhauer, redesenha novamente sua teoria dos instintos: ele opõe os instintos de vida aos de morte e explica os fenômenos da vida a partir da ação oposta e coordenada de ambos os instintos, aos quais a morte coloca um fim (HÜBSCHER, Denker gegen den Strom, p. 271). Segundo B. Nitzschke, assim como Freud, que parte diretamente de Schopenhauer, o filósofo "ensinou a dialética dos instintos de Eros e Tânatos (da Vontade de viver e da Vontade de negação da vida" (Cf. NITZSCHKE, Zur Herkunft des Es, p. 1119). Nitzschke também chamou a atenção, em outro lugar, à aceitação 
reconduzem, em primeira linha, a hipótese do instinto de morte às considerações de Schopenhauer ${ }^{32}$; enquanto que outros o fazem com todo o dualismo instintivo e tardio de Freud ${ }^{33}$. Esses comentadores documentam ${ }^{34}$ que a recepção de Freud possui as claras marcas de convencimento, ou seja, Freud teria "entrado (eingelaufen) efetivamente no porto da filosofia de Schopenhauer, com seu dualismo tardio dos instintos de morte e de vida. Muitos intérpretes vão tão longe a ponto de assumirem que se trata do mesmo porto do qual Freud "partiu (ausgelaufen)".

Em seu apelo a Schopenhauer em $A P P$, Freud cita o filósofo quando afirma que "nós, de repente, desaguamos no porto da filosofia de Schopenhauer, para quem, de fato, a morte é o 'resultado próprio', e neste sentido, o fim (Zweck) da vida, enquanto que, por outro lado, o instinto sexual é a corporificarão da Vontade de viver" (GW XIII, 53). A citação provém - e Freud indica a fonte em uma nota de rodapé - de um texto de Schopenhauer intitulado por [Especulação Transcendente] Sobre os Tons de Intencionalidade no Destino dos Indivíduos, datado do ano de 1851. Toda essa passagem, à qual Freud faz referência, diz o seguinte:

Então, aquela condução invisível, e que somente se manifesta com uma aparência duvidosa, nos acompanha até a morte, esse resultado próprio, e neste sentido, fim (Zweck) da vida. Nas horas da mesma, impelem, conjugam-se e entram em ação todas as forças secretas (que justamente se enraízam em nós mesmos), e que determinam o destino eterno dos homens. A partir de seus conflitos, se oferece o caminho que o homem tem, agora, para marchar; se prepara, assim, sua palingênese (renascimento), junto com todas as dores e proveitos (Wobl und Wehe) que estão nela compreendidos, e se determina a partir do mesmo de um modo irrevogável (P I, 236-37).

de Freud, a partir de Schopenhauer, do "pressuposto de ambos - uma teoria dos instintos - organizada de modo dualístico"; a qual envolve, no caso da teoria tardia, "uma oposição entre instintos de vida e de morte" (cf. NITZSCHKE, Die reale Innenwelt, Anmerkungen zur psychischen Realität bei Freud und Schopenhauer, p. 7). P. Gay abandonou ao leitor a tarefa de pagar os decisivos vencimentos pela seguinte afirmação: "Recordem-se do que Freud escreveu no verão de 1919 à sua boa amiga, Lou Andreas-Salomé: a respeito dos instintos, ele topou com uma ideia rara e lê tudo o possível [a seu respeito], inclusive Schopenhauer. O resultado foi sua concepção de (...) Eros e Tânatos, que batalham eternamente um contra o outro" (Cf. GAY, Freud, eine Biographie für unsere Zeit). Um exagero dessas considerações encontramos em M. Kaiser-El-Safti, que afirmou que não apenas "existem no sistema de Schopenhauer os instintos de vida e os instintos de morte" (KAISER-EL-SAFTI, op. cit., p. 200), como que Freud teve na obra de Schopenhauer a fonte "verdadeira" e "mais importante" de sua doutrina dos instintos tardia, o que porém ele nunca quis admitir abertamente (Idem, p. 195 e ss.).

${ }^{32}$ Cf. RANSOM, op. cit., p. 449; BRUN, op. cit., p. 85 e ss.; JONES, op. cit., p. 294; BERNHARD, op. cit., p. 118 e ss.; DIMITROV, op. cit., p. 73 e ss.; ELLENBERGER, op. cit., p. 710; RATTNER, op. cit., p. 17.

${ }^{33}$ Cf. GRANJEL, op. cit., p. 125; HÜBSCHER, op. cit., p. 273; NITZSCHKE, op. cit., p. 7; (1985), op. cit., p. 1119; CLEGG, op. cit., p. 39; GAY, op. cit., p. 452; KAISER-EL-SAFTI, op. cit., p. 195 e ss., especialmente p. 200.

${ }^{34}$ Cf. notas 24 e 25.

Voluntas: Revista Internacional de Filosofia - periodicos.ufsm.br/voluntas - Santa Maria - Vol. 9, n. 2, jul.-dez. 2018, p. 151-179. 
O significado exato desse trecho pode ser deduzido de seu contexto. Esse contexto é o ensaio como um todo, ou, considerado mais amplamente, a metafísica da Vontade schopenhaueriana. O texto correspondente, porém, não trata nem de um dualismo instintivo, nem de morte. A bem da verdade, o vocábulo "morte" aparece uma única vez nesse ensaio, de modo que adquire, em comparação com outros textos de Schopenhauer, uma importância significativamente menor ${ }^{35}$. Como se apercebe já no título, esse texto de Schopenhauer aborda a dependência entre o caráter e o destino. Em suma, Schopenhauer chega, nele, à conclusão de que, "assim como cada um é o diretor do teatro secreto de seus sonhos, igualmente, também aquele destino que comanda o nosso curso vital e efetivo, provém, de certo modo, e primeiramente, daquela Vontade, a qual é a nossa própria, e que, fazendo o papel do destino, age desde uma região situada muito além de nossa consciência individual e representadora" (PI 232). Nesse trecho, deixa-se perceber que "aquela condução à morte, que se apresenta apenas por meio de uma aparência duvidosa e invisível”, se relaciona com a nossa própria vontade, a qual, porém, encena nosso destino não de modo consciente, mas inconscientemente (unbewußt).

É desconcertante que Freud, que aparenta partir de paralelos evidentes entre sua teoria tardia dos instintos e a filosofia de Schopenhauer, não seja capaz de nos fornecer referências de fontes correspondentes, mas cite um texto que nos leva à consideração de Schopenhauer do destino que se prepara a si próprio. Em conexão com a tese psicanalítica da escolha inconsciente do destino (unbewußten Schicksalswab), Freud teria toda razão para citar ${ }^{36}$ esse texto de Schopenhauer. Contudo, o vínculo com seu dualismo tardio dos instintos permanece aqui obscuro.

$\mathrm{Na}$ busca pela clarificação dessa circunstância, voltemo-nos àquela expressão de Schopenhauer que pode ter produzido essas conexões duvidosas: a locução schopenhaueriana da "morte, esse resultado próprio, e nesse sentido, fim (Zweck) da vida". O que Schopenhauer quis dizer com essa expressão, e até que ponto seu conteúdo é compatível com a frase de Freud, o "alvo (Ziel) de toda a vida é a morte"? Essa pergunta também é importante pelo fato de Schopenhauer ter empregado aquele termo inúmeras vezes ${ }^{37}$. Ora, Schopenhauer apresentou uma plenitude de indicações sobre o fim (Zweck) da vida. Sendo assim, é falso superestimar a importância da sentença citada na filosofia schopenhaueriana. Para escolher apenas algumas dessas indicações, Schopenhauer também qualificou a necessidade e o sofrimento (Not und Leiden, W II, p. 696, P II, p. 309), assim como a auto-renegação ou o conhecimento (Selbstverleugnung oder Erkenntnis, W II, p. 695), como fins da vida. Disso se segue que o peso que Freud e muitos de seus comentadores atribuíram à sua expressão da morte

\footnotetext{
${ }^{35}$ Cf. WAGNER, Ensyklopädisches Register zu Schopenhauers Werken, p. 411, vocábulo "morte”.

${ }^{36}$ ELLENBERGER, Das menschliche Schicksal als wissenschaftliches Problem, p. 576-610, sobretudo p. 585 e $597-$ 605.

${ }^{37}$ W II, p. 732; W I, p. 367.
} 
como o "fim da vida" é inadequado, e já pela razão de que, para Schopenhauer, a morte é apenas um fim da vida entre muitos.

Para esclarecer a questão de em que medida a expressão de Schopenhauer da "morte, esse resultado próprio, e nesse sentido, fim (Zweck) da vida" tem algo em comum, em termos de conteúdo, com a frase freudiana de soar semelhante: "O alvo (Ziel) de toda a vida é a morte", será aclarada, antes de mais nada, a conclusão decisiva a que chegou Freud em APP. Depois de ter destacado o caráter impulsivo (triebhafte) da compulsão à repetição, Freud especulou que todos os instintos queriam restabelecer algo mais antigo (GW XIII, 38). Caso se desse continuidade a essa hipótese, então todos os êxitos do desenvolvimento orgânico deveriam ser reconduzidos, consequentemente, a influências desviantes, estorvadoras e externas:

O ser vivo elemental teria desejado, desde seu início, não ter se transformado (...) A natureza conservativa dos instintos não é compatível com a ideia de que o alvo da vida fosse uma situação nunca alcançada anteriormente. Esse alvo deve consistir, pelo contrário, em um estado original que o ser vivo abandonou um dia, e ao qual se esforça por retornar, por meio de todos os desvios do desenvolvimento. Se pudéssemos aceitar como uma experiência sem exceção que toda a vida morre e retorna ao reino inorgânico a partir de causas internas, então, poderíamos dizer: o alvo de toda a vida é a morte, e estabelecer que: 0 nãovivo existiu antes do vivo (GW, XIII, 40).

Até o fim do texto, Freud procura alicerçar essa conclusão sobre uma fundamentação energético-fisicalista (energetisch-physicalischen). Ele estabelece como uma tendência universal do instinto a de, "principalmente, deixar o aparelho anímico sem excitação, ou manter a quantia da excitação nele constante ou a menor possível". E com base nisso, conclui: “(...) Nós notamos que a função assim determinada participaria do esforço mais universal da vida, a de regressar à paz do mundo inorgânico" (GW XIII, 68).

Com isso, Freud postula a existência de um instinto ativo, que tem o fim de conduzir o organismo à morte. Defende que, no mundo orgânico, uma "tendência" (Streben) ou "impulso" (Drängen) orgânico, somático-biológico e ativo, persegue a morte. E por consequência, antes de uma "falha de funcionamento" (Betriebsunfall), ou um acontecimento sofrido passivamente, a morte se corresponde, para Freud, com uma finalidade biológica. Ela é o resultado de uma intencionalidade cega e determinada (zielgerichteten, blinden Absichtigkeit) ${ }^{38}$.

Esse parece ser o conteúdo que Freud e alguns de seus comentadores viram na expressão de Schopenhauer da "morte, esse resultado próprio, e nesse sentido, fim (Zweck) da vida”. Uma interpretação assim, porém, não teria sido definida no sentido de Schopenhauer. O equívoco aqui existente parece ter sido causado pelo termo fim

\footnotetext{
${ }^{38}$ Para uma exposição mais detalhada da argumentação do instinto de morte, cf. BRUN, op. cit., p. 82 - 86.
} 
(Zweck) da vida. Fim da vida pode significar, em primeiro lugar, alvo (Ziel) da vida, e ser entendido teleologicamente. Nesse significado repousa o ponto de partida para uma interpretação biológica do termo. Contudo, o termo "fim (Zweck) da vida" também pode ser entendido de modo ético e pedagógico. Semanticamente, estaríamos lindando com o significado (Bedeutung) que é atribuído à vida. Nos moldes da interpretação da morte de Schopenhauer, o fim (Zweck) comporta essa última conotação. Schopenhauer não disse, de modo algum, que a morte é o alvo (Ziel) da vida em um sentido biológico. Antes disso, ele lhe adjudicou uma relevância ética e pedagógica. E sendo assim, defendeu a interpretação de que deve ser atribuída à morte um significado (Bedeutung) incomparável.

Isso pode ser explicado da seguinte maneira: a conclusão (Vollendung) e a salvação (Erlösung) do homem são alcançadas, segundo Schopenhauer, como se sabe, na total negação da Vontade 39 . A negação da Vontade consiste, portanto, no "mais elevado alvo (Ziel) moral" (PII, 328). O "fim (Zweck) da vida" propriamente dito não deve ser encontrado, portanto, para Schopenhauer, em nada senão na negação da Vontade: "Como o fim (Zweck) da existência se deve indicar, propriamente, nada senão o conhecimento (Erkenntnis) de que seria melhor inexistir. Essa (...) é a mais importante de todas as verdades" (W II, p. 695). Por conseguinte, a negação da Vontade é o "verdadeiro fim da vida" (wahre Zweck des Lebens, W II, p. 731).

O que acontece, porém, com as outras atribuições de Schopenhauer do "fim da vida"? Diante dessa última declaração, elas ainda assim merecem ser citadas como fins importantes da vida? A resposta de Schopenhauer é: sim. Elas conduzem (leiten), ou educam (erziehen), isto é, potencializam (potentia) a negação da Vontade, enquanto o fim mais elevado. A rigor, contudo, se trata, aqui, apenas de meios para o fim propriamente dito da vida, ou fins vitais subordinados, ordenados hierarquicamente segundo o seu potencial de impulso (Antriebepotentialls) à negação da Vontade. Essa "hierarquia dos fins da vida" pode ser deduzida com base na seguinte consideração:

\footnotetext{
Assim, todos acreditam que têm o mais justo direito à felicidade e à satisfação: como geralmente acontece, porém, a felicidade e a satisfação se furtam à sorte das pessoas, e então, se acredita que aconteceu uma injustiça, e que realmente, se falhou diante do fim da existência. Por outro lado, é muito mais acertado considerar o trabalho, a privação, a necessidade e o sofrimento, coroados (gekrönt) com a morte, como o fim de nossa vida (...), uma vez que eles são os condutores da negação da Vontade de viver (W II, p. 671).
}

Como pode ser inferido dessa passagem, a morte ocupa uma categoria muito alta na "escala dos fins da vida (Lebenszwecke)": evidentemente, porque ela dirige, segundo Schopenhauer, e mais do que outros fenômenos da vida, à negação da

\footnotetext{
${ }^{39}$ Cf. W I, Livro 4.
} 
Vontade; e por conseguinte, ao mais elevado alvo (Ziel) moral, bem como à salvação. Seu significado ético e pedagógico não deve ocultar, todavia, o fato da morte não ser o alvo (Ziel) ou o fim (Zweck) da vida em si mesmo, mas meio, motivo (Antrieb) para tanto: "A morte, na medida em que é um sofrimento, é um impulso (Antrieb) à salvação, não, porém, a própria salvação” (HN I, p. 163).

Como, porém, Schopenhauer veio a conceder à morte uma importância tão elevada como preparadora do caminho (Wegbereiter) à negação da Vontade? Uma parte da resposta a essa pergunta se encontra na concepção supracitada: a morte provoca o sofrimento, e o sofrimento vence (bricht), segundo Schopenhauer, a Vontade (HN I, p. 393). Nós achamos, porém, que a parte interessante da resposta se encontra, justamente, naqueles conceitos aos quais Freud se referiu em APP. Schopenhauer afirma, deveras, que na hora da morte, "todas as forças secretas (que se enraízam justamente em nós mesmos), e que determinam o destino eterno dos homens", se conjugam e entram "em ação". Bem longe de postular uma finalidade no sentido de uma passagem para o estado inorgânico, Schopenhauer tematiza, aqui, a força de iluminação (Erleuchtungskeraft) das horas próximas à morte. Diversas vezes, o filósofo se referiu ao poder dos últimos dias ou horas antes da morte. Eles propiciam um nível elevado de integração (Integrationsniveau) nunca antes alcançado na vida, o que possibilita uma mudança de afinação (Eintstelungenthung): "O completo curso da vida, vislumbrado respectivamente nas horas da morte, exerce sobre a Vontade um efeito análogo àquele desempenhado pelo motivo no agir do homem: lhe confere uma nova direção, que coincide com o resultado (Resultat) essencial e moral da vida" (W II, p. 733). Nesse momento, se destaca um ponto de vista que foi descuidado pelos comentadores: geralmente, aceita-se que, em Schopenhauer, a negação da Vontade se produz a partir de uma união do conhecimento intuitivo e da ascese radical. Como se sabe, Schopenhauer expôs isso no primeiro tomo de $M V R$. Posteriormente, e de modo alternativo, ele enunciou que a visão correta (die richtige Einsicht) no limiar da morte é suficiente para, de certo modo, e segundo uma lei-de-tudo-ou-nada (Allesoder-Nichts-Gesetz), suspender a Vontade ${ }^{40}$. Esse momento (Moment) econômico, que condecora a visão correta da hora da morte diante de outras estratégias de negação da Vontade, também parece ser sugerido pelo fato de Schopenhauer atribuir repetidamente à morte um significado incomparável (unvergleichische Bedeutung).

\footnotetext{
40 Schopenhauer chama a atenção sobre essa circunstância em outro momento, quando escreve o seguinte: "Nas horas da morte se decide se o homem recai no ventre da natureza, ou porém se não pertence mais ao mesmo" (W II, p. 699).
} 
$\mathrm{Na}$ literatura correspondente, não somente a expressão de Schopenhauer de "a morte, esse resultado próprio, e nesse sentido, fim da vida" foi interpretada no sentido de uma hipótese do instinto de morte, ou mesmo, de um monismo do instinto de morte. Mas muitos intérpretes foram ainda mais longe e propuseram o tópos da afirmação e negação da Vontade de vida de Schopenhauer como uma antecipação do dualismo dos instintos de vida e de morte de Freud ${ }^{41}$. Na sequência, creio demonstrar não apenas que essa concordância também inexiste factualmente, como que, pelo contrário, a marcante diferença nos dualismos de ambos os autores deve ser acentuada como uma característica de suas abordagens.

Para Schopenhauer, é, antes, “(...) a polaridade, isto é, a contradição de uma força (Kraft) em duas funções (Tätigkeiten) qualitativamente opostas, distintas e que se esforçam por uma reunificação (zur Wiedervereinigung strebende) (...) um tipo fundamental (Grundtypus) de quase todos os fenômenos da natureza” (W I, p. 171). De fato, a polaridade fundamental, segundo Schopenhauer, ocorre entre a Vontade e o intelecto, e à dicotomia da afirmação e da negação da Vontade não corresponde nenhum dualismo instintivo (Trieb-Dualismus), mas um dualismo do instinto (Trieb, afirmação da Vontade) e da supressão do instinto (Aufhebung des Triebes), por meio do intelecto (negação da Vontade). A essa diferença qualitativa de sentido se acrescenta outra formal e quantitativa, a saber, Freud postula uma equipolência do adversário, enquanto que, em Schopenhauer, é o oposto o que ocorre: a Vontade de viver comanda, ela é o "conteúdo interno, o essencial do mundo", enquanto que a vida e o mundo visível, pelo contrário, não são nada senão um "fenômeno, (...) espelho da vontade" (W I, $\left.\int 54\right)$. Schopenhauer defende, portanto, um monismo do instinto de vida (Monismus des Lebenstriebes). A negação [da Vontade] de Schopenhauer não se corresponde, sequer, com uma entidade autóctone (autochthonen), dado que também é, por princípio, destituída de força (machtlosen). Seu caráter ela o obtém apenas como negação da Vontade de viver. Ela não é, portanto, um instinto (Trieb), mas uma inibição do instinto (Triebhemmung), ou uma renúncia do instinto (Triebeverzichst). Essa abnegação não é, novamente, para Schopenhauer, algo condicionado organicamente, mas o resultado de um ato de consciência e de conhecimento. Esse ato, conforme o filósofo, se manifesta raramente, e pressupõe uma "visão trans-racional" (tranzrationalle Einsicht), que deve "se avizinhar desde fora" (von Aussen angeflogen

\footnotetext{
41 “A negação da Vontade de viver, oposta por Schopenhauer à afirmação da Vontade de viver, se encontra novamente na obra de Freud como Tânatos, como instinto de morte" - lemos em Nitzschke (NITZSCHKE, 1978, op. cit., p. 73). Para além disso, Freud, conforme esse autor, pode ser reconduzido a Schopenhauer não só pelo instinto de morte, mas pelo paradigma instintivo e psicanalítico tardio dos instintos de morte e de vida como um todo. Com isso, ele se refere ao dualismo da afirmação e negação da Vontade de viver (NITZSCHKE, 1985, op. cit., p. 1119; também CLEGG, op. cit., p. 39]. Na fundamentação dessa asserção sempre se falhou.
} 
kommen), e que, neste sentido, pode ser entendido como um "efeito da graça" 42 . Completamente nas antípodas de Freud, que entende a vontade de morte (Willen zum Tod) como a expressão natural da vida instintiva (GW XII, 60), em Schopenhauer, a negação da Vontade de vida "está em plena oposição à direção (Richtung) natural da espécie humana". Ela é pautada por "uma resoluta adversidade à natureza” (W II, p. 723).

Admitido esse esclarecimento, pode-se perguntar como que Schopenhauer determina a relação entre a Vontade de viver onipresente e a morte. Na realidade, segundo o filósofo, a onipresença da Vontade de viver se estende para dentro do domínio da morte. A morte é entendida, em Schopenhauer, como a expressão da Vontade de viver, na medida em que o nascimento e a morte formam uma oposição apenas aparente, que se furtou ao plano metafísico e profundo da "Vontade de viver". Não lidamos aqui, portanto, como no caso de Freud, com um contraste entre a vida e a morte, mas com uma oposição entre o mundo fenomênico, no qual ambos estão inseridos, vida e morte, e o mundo real da coisa em si, que como se sabe, para Schopenhauer, é a Vontade de viver. A morte não consiste em nada além de um retorno à unidade metafísica da Vontade de viver (W II, p. 596). Sobre esse pano de fundo, ela aparece, grosso modo, como uma "ilusão" (W II, p. 287), um "mero fantasma, que assusta os fracos", ou de fato, como uma piada (W II, p. 555). Essa visão da morte é sempre muito representativa (repräsentativ) para a concepção de morte das "sociedades metafísicas" 43 , que se distinguem por (a) o entendimento da morte como o retorno ao reino original (Urreine), (b) a crença na transmigração das almas e (c) a consideração da morte como a separação entre duas coisas. A morte é interpretada, em Schopenhauer, significativamente, ainda a partir da pergunta do que vem depois da morte. A consideração da morte de Freud já revela, pelo contrário, as características da interpretação mortuária específica das “sociedades modernas". Ela se delineia junto a um claro distanciamento da metafísica-dos-dois-mundos (zweiWelten-Metaphysik). Existe, somente, o único mundo (die eine $W e l t)$, no qual nós estamos. Deus e infinitude são entendidos como criações dos homens e estão amplamente eliminados. Como é percebido claramente em Freud, a morte não é entendida, como ainda no caso das "sociedades metafísicas", como algo que vem depois da vida, mas como um fenômeno desse lado, como algo que já age (wirkt) na vida. Por isso, é uma especificidade de Freud que ele entenda essa ação não de maneira existencial-ontológica, mais ou menos como Heidegger, Jaspers ou Sartre, mas de modo completamente biológico. Essa mudança característica entre a época de

\footnotetext{
${ }^{42}$ Cf. ZENTNER, Der Selbstmord als Antwort auf das Leid bei Schopenhauer, in: Freiburger Zeitschrift für Philosophie und Theologie, p. 433-448, especialmente 444 e ss.

43 Cf. aqui a correspondente exposição de Morin (MORIN, L'bomme et la mort dans l'bistoire) e Saner (SANER, Das Sein zum Tode aus philosophischer Sicht, p. 464 - 469).
} 
Schopenhauer e a de Freud na compreensão da morte, naturalmente, não é desimportante para o entendimento das diferenças aqui pontuadas.

A diferença, talvez, mais profunda entre a negação da Vontade de viver de Schopenhauer e o instinto de morte de Freud repousa em suas valências eudemonológicas e morais inversas. Enquanto o fundador da psicanálise enxerga uma fonte principal do mal e do sofrimento no âmbito do instinto de morte, Schopenhauer vê na negação da Vontade de vida, de modo diametricalmente oposto, o alvo (Ziel) moral mais elevado e o acesso a uma felicidade que, certamente, não parecem pertencer a este mundo. De modo inversamente correspondente, ocorre o mesmo com os valores de seus adversários, o instinto de vida e a Vontade de viver: em sua carta aberta a Albert Einstein, Freud opôs aos instintos eróticos, "os que conservam, querem conservar e agregar", os instintos de destruição ou agressão, que "querem matar e destruir" (GW XVI, 23); e levantou a pergunta de como Eros poderia se opor a Tânatos, ao patamar da questão do destino da humanidade (GW, XIV, 506). Para Schopenhauer, pelo contrário, não é necessário nenhum adversário do instinto de vida para explicar o mal no mundo, pois a Vontade de viver é, em si mesma, destrutiva. Os fenômenos de agressão, crueldade, egoísmo e injustiça podem ser deduzidos imediatamente daquela (W I, \ 65), enquanto que Freud recorre, como já dito, ao adversário do instinto de vida para a explicação desses fenômenos. Disso se origina a interessante relação de que, para Freud e Schopenhauer, a "libertação" (Rettung) do homem é garantida por meio de princípios opostos um ao outro, tanto em sentido ético como eudemonológico. Em Schopenhauer, por meio da negação do instinto de vida (Verneinung des Lebenstriebes), e em Freud, através da "afirmação" (Bejahung) do mesmo. Inversamente, salta para o primeiro plano, como a característica fundamental do sentido de ambos os pensamentos, o fato de que eles compartilham a consideração pessimista de uma destrutividade constitucional humana, que deriva, porém, de qualidades instintivas (Triebqualitäten) antitéticas: em Schopenhauer, a partir da Vontade de vida, e em Freud, a partir da "vontade de morte (Willen zum Tod)".

Como isso pode ser entendido, em seus pormenores? O instinto de destruição, conforme Freud, não é senão a autoagressão alienada (veräußerte Autoaggretion), que provém da tendência do instinto de morte à autodissolução (Selbstauflösung). Que a transição da tendência à autodissolução para a tendência à autodestruição (Selbstzerstörung), bem como a transição do desejo pela tranquila autodissolução (stiller Selbstauflösung) no Nirvana para a autoagressão brutal, não sejam tão evidentes assim e precisem de um aclaramento que Freud nunca forneceu, pode não nos ocupar nesse momento. Em suma, se o homem não deseja sucumbir à autodestruição, que é ditada pelo instinto de morte, ele deve destruir os outros. A agressão contra os outros, portanto, para Freud, se torna a condição da auto-conservação: “O homem preserva, por assim dizer, a sua própria vida, na medida em que destrói o outro” (GW XVI, 22). Esse dilema, dado pela existência do instinto de morte, de destruir a si próprio 
ou o outro, e que o Freud tardio viu apresentado aos homens, é constitutivo em seu pessimismo.

Schopenhauer parte de uma destrutividade constitucional semelhante, a qual se funda, porém, na Vontade de viver. $\mathrm{Na}$ base da natureza monístico-metafísica da Vontade sempre está a única Vontade (der eine Wille), que aparece em todos os indivíduos da espécie humana. Por isso, "todos querem possuir tudo, ou pelo menos comandar, e o que se opõe a isso, desejam aniquilar" (W I, p. 391). O núcleo da natureza está em todo indivíduo, cada um é toda a Vontade de viver. "Sendo assim, quer se trate apenas de um inseto ou de um verme, a natureza dirá a partir dele: 'Somente eu sou o todo no tudo (Alles in Allem): na minha conservação está tudo em jogo, o resto pode desabar, pois não é propriamente nada” (W II, p. 689). Por isso, a própria afirmação da Vontade vai, facilmente, tão longe a ponto de invadir o espaço da afirmação da Vontade no outro, e tentar exterminar nos outros a Vontade de viver. Dessa condição que surgem, para Schopenhauer, a injustiça, a maldade e a crueldade no âmbito interpessoal. Sendo assim, a agressão e a destrutividade não são produzidas, como para Freud, a partir de uma força autóctone (autochtonen) e independente do instinto de vida. Pelo contrário, esses fenômenos remetem a "estados agregados (Aggregatszustände)" de uma Vontade de viver hipertrófica (bypertrophen). Schopenhauer deduz, assim, a agressividade e a destrutividade, como é característico de ensaios biológicos, de um instinto de auto-conservação. É esse potencial de destruição que constitui, de modo decisivo, aqueles tormentos e sofrimentos incomensuráveis da espécie humana, que conduziram Schopenhauer ao célebre e polêmico posicionamento contra Leibniz: "De fato, podemos opor, séria e honestamente, à argumentação evidentemente sofística de Leibniz̧, de que o nosso mundo é o melhor entre os possíveis, a concepção de que ele é o pior entre os possíveis" (W II, p. 671).

\section{IV}

Depois da tematização das profundas diferenças entre as teorias de Freud e de Schopenhauer, algumas semelhanças específicas também podem ser pensadas. Definitivamente, não é defendido por muitos autores a existência de semelhanças, já que a maioria sequer apresenta os fundamentos que propiciem a elaboração de conexões. Pois bem, o paralelo entre o instinto de morte e a negação da Vontade de vida parece se basear no fato de que ambos os autores vinculam suas concepções ao conceito de "Nirvana". Enquanto que, para Freud, o instinto de morte está subordinado ao assim denominado princípio de Nirvana, que deve exprimir a tendência do instinto de morte a "zerar as tensões e excitações” (GW XIII, 372), Schopenhauer nomeia o estado final da negação da Vontade, repetidas vezes, de "Nirvana" (W I, p. 487; P II, p. 342). Com essa expressão, o filósofo se refere a um estado que se distingue pela "paz", "profunda tranquilidade" e "silêncio marítimo da bem- 
aventurança" (W I, p. 486). No sentido de uma "libertação ou equilíbrio (Ausgleichs)" de todas as tensões, deixa-se ver, assim, o denominador comum do entendimento de Schopenhauer e de Freud do "Nirvana". Na medida em que, para Freud, o instinto de morte corporifica a "tendência dominante na vida anímica (...) por redução, conservação constante, apagamento da sensação de tensão interna” (GW XIII, 60), o alcance do Nirvana é, para o fundador da psicanálise, indefectivelmente, préprogramado por um instinto. O estado de um equilíbrio de todas as tensões se torna, à luz dessa consideração, um objetivo instintivo infalível (verfeblbaren), e a obtenção do Nirvana se revela como uma constância fundamental do ser humano. Schopenhauer, pelo contrário, enxerga o Nirvana como o resultado da negação da Vontade de viver, o que pressupõe um ato de força (Kraftakt) do intelecto, "despotencializado" constitucionalmente por Schopenhauer, contra uma natureza irracional e selvagem; e que, ademais, não entra em cena intencionalmente, mas por meio de um "efeito da graça". Nada além desse acontecimento numinoso autoriza, em Schopenhauer, a superação naturalístico-ubiquitária (naturalistisch-ubiquitäre Ermächtigung) do instinto de vida garantida por Freud [com os instintos de morte]. Ou seja, a orientação quietista, de fato, é comum a ambos os autores, e por pouco, Freud não soa muito igual a Schopenhauer, em sua crítica (Beurteilung) ao instinto de vida, com a expressão da "libertação do estorvo" (GW XIII, 69), e a qual recorda a afirmação de Schopenhauer de que: "Também se pode considerar nossa vida como um episódio incômodo e inútil na paz salina do nada" (P II, p. 318). A diferença entre ambos os autores se encontra no fato de que o Nirvana permanece, para Schopenhauer, como um ideal. Ou seja, a relação do homem com o Nirvana enquanto o estado de plena paz e ausência de excitação é definido por ambos de modo fundamentalmente distinto: no lugar de uma referência real de Freud ao Nirvana, há, em Schopenhauer, uma referência apenas ideal. O ideal incontestavelmente quietista de Schopenhauer se tornou, em Freud, uma realidade quietista, que está ancorada na vida instintiva humana.

Quando retrocedemos o nosso olhar e tomamos a teoria tardia dos instintos de Freud como o ponto de partida para uma comparação com alguns motivos fundamentais da filosofia de Schopenhauer, encontramos tanto paralelos substanciosos, como outros descuidados.

Em primeiro lugar (1894 - 1897), Freud analisou os conflitos psíquicos sob o ponto de vista de "desejos" ou "representações" que entram em conflito uns com os outros. Ele falou de "incompatibilidades" na vida representativa de seus pacientes, que deveriam fornecer ocasião para doenças neuróticas (GW, I, 61s.; 447s). Posteriormente (1897-1911), Freud entendeu as "representações" e os "desejos" conflitantes, progressivamente, como derivados dos instintos. E nessa base, avançou a uma concepção comumente conhecida como a primeira teoria dos instintos, e a tardia: “Oposições entre representações são apenas a expressão [de oposições] entre os próprios instintos. De significado completamente especial para a nossa tentativa 
de explicação é a inegável adversidade entre os instintos que servem à sexualidade, isto é, à obtenção do prazer sexual, e os demais, cujo alvo é a auto-conservação do indivíduo, ou os instintos de eu" (GW, VIII, 97). No ano de 1914, Freud chegou a uma nova formulação dessa teoria. A nova concepção era, então, a de que os instintos de eu e os sexuais resultavam de uma energia fundamental e comum, que poderia ser designada como libidinosa (GW, V, 113). Dado que Freud manteve a diferença entre ambos os grupos, não chegou a romper com sua teoria original dos instintos, pois entendeu as novas modificações conceituais como um prolongamento daquela teoria: "A separação da libido em uma tal que seja própria ao eu, e outra que se dirige ao objeto, é uma extensão imprescindível de uma primeira hipótese que isola os instintos sexuais e os de eu" (GW, X, 141). A remissão da neurose a um conflito entre ambas as tendências permanece o mesmo. Ao invés dela ocorrer entre os instintos sexuais e os de eu, se dá entre os instintos de eu e os de objeto, ambos de natureza libidinosa (GW, XIII, 66).

Freud não foi original na acentuação da relevância psicopatológica do paradigma instintivo e dualístico dos instintos de auto-conservação e sexuais. Um grande número de psicopatologistas do fin de siècle reconduziram, antes de Freud, as doenças psíquicas a esse dualismo. Historiadores da ciência veem nisso a influência de Darwin, que forneceu os moldes teoréticos necessários, sobre cujo pano de fundo os instintos de conservação da espécie e de si mesmo, e nenhum outro, puderam ser reconhecidos como a base de todo o comportamento animal ${ }^{44}$.

A princípio, esses motivos podem ser encontrados já em Schopenhauer. Em primeiro lugar, Schopenhauer conferiu à Vontade de viver, em si mesma monística, dois grandes setores temáticos (thematische Sektoren), em que ela se objetiva: o da autoconservação e o da propagação. Não diferentemente de Freud, Schopenhauer concebeu os instintos de auto-conservação e os sexuais como forças instintivas fundamentais e únicas do homem: "A auto-conservação é a sua primeira aspiração, e tão logo o homem a soluciona, aspira pela propagação da espécie: mais do que isso, o homem não pode querer, enquanto um ser meramente natural" (W I, p. 389). É, de fato, digno de atenção que Schopenhauer também tenha descrito o que foi igualmente tematizado por alguns pesquisadores do fin de siècle, sobre a importância psicopatológica desse modelo instintivo. O filósofo sinalizou ao fato de que ambos os influxos instintivos não poderiam coexistir pacificamente, mas cairiam forçosamente em conflito. O filósofo foi tão longe a ponto de dizer que, em última instância, esse conflito é o que mina com o bem-estar psicológico e físico do homem. Nesta direção, o pessimista Schopenhauer explicou que, sem o confronto mencionado, a existência humana seria "fácil e serena":

\footnotetext{
${ }^{44}$ Cf. SULLOWAY, Frend, Biologist of the Mind, p. 252.
} 
Se a Vontade de vida se apresentasse, meramente, como um instinto de auto-conservação, então, ela seria apenas uma afirmação do fenômeno individual, no espaço de tempo de sua duração natural. Os incômodos e as preocupações de essa vida não seriam grandes, e a existência resultaria branda e simples. Uma vez que, pelo contrário, a Vontade de viver quer, pura e simplesmente, para sempre, ela também se apresenta como instinto sexual, o qual abrange com a vista uma série de gerações. Esse instinto extirpa aquele sossego, placidez e inocência que acompanhariam uma existência meramente individual, e trazem transtorno e melancolia à consciência, assim como necessidades, preocupações e desastres ao curso da vida (W II, p. 651).

Se deduz dessa passagem que Schopenhauer entende as implicações da antítese entre os instintos de auto-conservação e os sexuais, no horizonte da gênese dos débitos psíquicos, não apenas a partir do ponto de vista de um conflito com o mundo externo, mas, como Freud também faz posteriormente, a partir da perspectiva de um conflito intrapsíquico (innerpsychischen Konfliktes). Assim, ele parte do fato de que os esforços instintivos antitéticos não minam apenas com a relação do indivíduo com o meio externo, por meio dos "desastres, preocupações e necessidades", mas, igualmente, e sem a necessidade de nenhuma interferência externa, podem agir de modo diretamente patogênico sobre a consciência do indivíduo, na medida em que lhe trazem "agitação e melancolia" 45 . Esse efeito "diretamente" patogênico precisou ser esclarecido, posteriormente, por Freud, por meio [do recurso à teoria] do mecanismo da repressão, ao qual deve ser remetido o conflito supracitado. A bem da verdade, poderíamos partir do fato de que, inclusive, a teoria freudiana da repressão foi antecipada por Schopenhauer até mesmo em seus pormenores ${ }^{46}$. Disso se segue que não exatamente a tardia, mas a primeira doutrina dos instintos de Freud, com sua correspondente teoria da repressão e do conflito instintivo, poderia ser reconduzida, enquanto um complexo global, a Schopenhauer.

\footnotetext{
$45 \mathrm{O}$ conflito entre ambos os influxos também se manifesta como algo relevante, segundo Schopenhauer, no que concerne ao casamento: "Todos têm a impressão de que devem, diante do casamento, escolherem entre o indivíduo ou o interesse da espécie” (W II, p. 654). O que Schopenhauer antecipou, aqui, é, em última instância, o ponto de vista econômico de que precisou partir Freud em sua formulação da primeira teoria dos instintos: "Nós também vemos que, na prática, há uma oposição entre a libido de eu e a libido objetal. Quanto mais uma delas se consome, mas a outra se empobrece" (GW, X, p. 141). Outras analogias à interpretação de Freud de que o "conflito patogênico (...) é tal que ocorre entre os instintos de eu e os instintos sexuais" (GW, XI, p. 363) se encontram, em Schopenhauer, no capítulo intitulado por Metafísica do amor sexual, do segundo tomo de $O$ Mundo como Vontade e Representação. Por exemplo, sua menção da "guerra" que o "gênio da espécie (instinto sexual)" realiza, "sem exceção, contra o gênio protetor do indivíduo" (instinto de auto-conservação), enquanto seu "perseguidor e inimigo". Como também sua observação de que as exigências da paixão sexual são muitas vezes incompatíveis "com a conduta pessoal dos cidadãos", ou que "colidem" com a última, e etc.. Nessas passagens, lemos claramente que o instinto sexual se encontra "em contradição" não apenas com as "relações externas com o meio", mas "com a própria individualidade" (W II, p. 650 e ss.).

${ }^{46}$ Cf. GÖDDE, Schopenhauer als Vordenker der Freudschen Metapsychologie, esp. 1011 - 1015. Mais em detalhes, nos ocupamos das experiências psiquiátricas de Schopenhauer no Charité de Berlim e do assassinato realmente acontecido de Demoiselle Thiele em: ZENTNER, Der Wabnsinn als Lethe unerträglicher Leiden; Addenda zu Schopenhauers Antizipation der Freudschen Verdrängungstheorie.
} 
Conclusivamente, no sentido de uma "teoria do erro" (Irrtumstheorie), podemos apontar algumas razões que possam ter propiciado a origem e a continuação da lenda aqui tematizada. Antes de falarmos das causas fundamentais da continuação dessa lenda, examinemos, brevemente, o que pode ter determinado sua origem, a saber, a interpretação falha de Freud, em $A P P$. Em primeiro lugar, e em vista da preocupação amplamente documentada de Freud com o problema da prioridade, é de se surpreender ${ }^{47}$ que ele conceda, tão solicitamente, a Schopenhauer, a antecipação de uma de suas descobertas; e mais ainda, onde não existem, propriamente falando, fundamentos para uma tal prioridade. Algum entendimento desse comportamento de Freud talvez possa ser alcançado caso nos recordarmos do que Peter Gay disse a esse respeito, a saber, que o positivista e anti-metafísico Freud nunca procurou indicar um filósofo como antepassado, e sobretudo, nos momentos em que isso seria mais plausível ${ }^{48}$. Para Gay, Freud é um oportunista (Opportunist), portanto, quando se trata de citações. Essa consideração está em acordo com a de Sulloway, segundo o qual o pai da psicanálise foi um estrategista de citações ${ }^{49}$. Desse modo, deveríamos nos perguntar por que teria sido oportuno a Freud atracar sua hipótese do instinto de morte no ideário de Schopenhauer. Uma revisão dos reconhecimentos de parentesco realizada por Freud ante Schopenhauer nos revela que somente no tema da sexualidade Freud esteve disposto a pagar um tributo comparável ao filósofo (GW 5 32; 14 105). Em relação ao tema da repressão e do modelo estrutural da personalidade (strukturellen Persönlichkeitsmodells) ${ }^{50}$, que também teriam todo o direito de serem reconduzidos ao sistema de Schopenhauer, Freud já permaneceu calado. Assim, existe um critério evidentemente discriminatório entre a repressão e o modelo estrutural da personalidade, por um lado, e a sexualidade e o instinto de morte, por outro: esse critério é o do escândalo (Anstößigkeit). Em oposição à consideração de que o "alvo (Ziel) de toda a vida é a morte", ou de que as neuroses têm uma origem sexual, a doutrina da repressão e a introdução de um modelo estrutural da personalidade, embora indubitavelmente significativos, não deixam de serem inovações pacíficas e desconectadas do elemento chocante do "pan-mortalismo" ou do "pan-sexualismo". Com base nisso, concluímos o seguinte: Freud parece ter reivindicado a antecipação

\footnotetext{
${ }^{47}$ Cf. MERTON, The Ambivalence of Scientists, p. 32 - 35. Merton concluiu, com base em uma revisão sistemática dos textos de Freud, que Freud em mais de cento e cinquenta casos específicos expressou uma preocupação com o problema da prioridade. Cf. a esse respeito também ELLENBERGER, op. cit., p. 612, e SULLOWAY, op. cit., p. 467 e ss.

48 GAY, op. cit., p. 173.

${ }^{49}$ Por essa informação me coloco em dívida com Frank Sulloway.

${ }^{50}$ Entende-se sob essa expressão a célebre estruturação de Freud da personalidade nas instâncias do id, eu e super-eu, também conhecidas com a denominação de "modelo estrutural da psique".
}

Voluntas: Revista Internacional de Filosofia - periodicos.ufsm.br/voluntas - Santa Maria - Vol. 9, n. 2, jul.-dez. 2018, p. 151-179. 
de Schopenhauer, sobretudo, quando essa indicação lhe possibilitava neutralizar a responsabilidade pelo escândalo e a estranheza de uma ideia. Dado que, no início desse século $[\mathrm{XX}]$, o muito lido Schopenhauer, de certo modo, valia como uma "autoridade espiritual", Freud podia aumentar a credibilidade de suas ousadas hipóteses [com a indicação do respaldo e previsão dessa autoridade]. Em poucas palavras: parece ter sido, nem tanto, o conhecimento sobre os paralelos efetivos, mas sim a necessidade de, por um lado, neutralizar, e por outro, assegurar uma tese estranha (befremdliche) com a referência à história das ideias, o que deu o motivo ao reconhecimento de parentesco sugerido por Freud ante Schopenhauer. Essas razões oportunistas parecem ter sido um grande obstáculo a uma interpretação mais $\operatorname{apropriada}^{51}$.

Como, porém, se interpreta a continuação dessa lenda? Os tópicos seguintes me parecem propiciar algum entendimento: em primeiro lugar, o próprio Freud aparenta ter procedido de modo completamente "fidedigno" (durchaus ,glaubwürdig"), uma vez que não apenas postulou as "amplas coincidências", como também, em seu postulado, partiu de uma indicação de fonte. Essa indicação contém a descrição da morte como o "resultado próprio, e neste sentido, o fim (Zweck) da vida", que não apenas parece se corresponder com a fórmula de Freud, "O alvo (Ziel) de toda a vida é a morte", como também é oposta, muito habilmente, ao instinto sexual, enquanto a “corporificação da Vontade de viver". Isso dá, efetivamente, a impressão de que se trata de uma pré-formulação da teoria instintiva e tardia freudiana. Por essa razão, um exame crítico pôde parecer desnecessário. Em segundo lugar, entre os gregos e Heidegger, nenhum outro filósofo, com exceção talvez Feuerbach, colocou a morte tão no centro de seu pensamento como Schopenhauer"52. "A morte é o gênio inspirador ou musa da filosofia (...) Dificilmente aconteceria (...) de nós filosofarmos sem a morte" (W II, p. 528-529). Essa interpretação, à qual Freud já havia se referido com simpatia em Totem e Tabu (GW, IX, 108), documenta a importância que Schopenhauer atribui à morte. Em terceiro lugar, a obra de Schopenhauer vale, na história da filosofia moderna, como modelo de pessimismo. Por isso, é natural que se coloque a hipótese do instinto de morte, que se destaca como um elemento pessimista na doutrina de Freud, em conexão com uma filosofia, na qual (a) o tema da morte ocupa uma posição central, e (b) que é geralmente designada como pessimista. Somente que: como vimos, o conceito do instinto de morte pode ser relacionado com

\footnotetext{
51 Outra comprovação dessa declaração avistamos no fato de Freud também ter falhado na interpretação de outro autor que procurou reivindicar como antepassado de sua teoria tardia dos instintos, a saber, Empédocles. As teses do grego sofreram na análise de Freud um destino semelhante ao de Schopenhauer: foram injustamente "biologizadas". Confira o que Seidmann escreve a esse respeito: "Freud subordinou Empédocles ao pensamento darwinista e olhou além dos problemas ontológicos e 'teológicos' essenciais dos pré-socráticos. Uma vez que Freud talha Empédocles conforme seus próprios objetivos, acabou sendo muito pouco justo com ele" (SEIDMANN, Religiöse und philosophische Wurzeln der Psychotherapie, Hinweise und Erwägungen, p. 358).

${ }_{2}$ Cf. FEUERBACH, Gedanken über Tod und Unsterblichkeit aus den Papieren eines Denkers, nebst einem Anhang theologisch-satirischer Xenien.
} 
Schopenhauer não pelo recurso ao pessimismo, dado que Schopenhauer deduz seu pessimismo da Vontade de viver, e por isso, a partir de uma oposição direta ao instinto de morte. Em quarto lugar, Freud reconheceu abertamente a natureza mitológica de sua doutrina dos instintos (GW, XV, 101). Já na "completa perplexidade das origens", não foi, de modo algum, segundo as palavras de Freud, a observação empírica, mas a ideia do poeta-filósofo Schiller de "que 'a fome e o amor' mantêm as molas do mundo unidas (daß ,Hunger und Liebe" das Getriebe der Welt zusammenhalten)" (GW14, 476), de onde partiu, prioritariamente. Com a reformulação desses primeiros ensaios, no ano de 1914, Freud permaneceu, como se sabe, comprometido com o mito de $\mathrm{Narciso}^{53}$. Por conseguinte, associou suas duas primeiras teorias instintivas a um modo de consideração mítico ou poético, de modo que não foi senão uma continuidade [desse método] a conexão de sua teoria instintiva tardia com um sistema filosófico ${ }^{54}$.

Com base nessas razões, podemos suspeitar que o postulado das amplas coincidências entre a teoria instintiva tardia de Freud e as considerações de Schopenhauer parece carecer de uma legitimação mais ampla. Afinal, como Freud uma vez respondeu, de acordo com Fritz Wittels, em sua biografia freudiana, e logo após a origem do pensamento do instinto de morte ter-lhe sido associada à morte de sua filha Sofia: "O Além [do Princípio de Prazer] foi escrito em 1919, quando minha filha estava sadia e florescente (...) A aparência nem sempre é a verdade” (GW, NB, 758) 55 .

\section{Referências bibliográficas}

ATZERT, S.. Zwei Aufsätze über Leben und Tod: Sigmund Freuds Jenseits des Lustprinzip und Arthur Schopenhauers Transscendente Spekulation über die anscheinende Absichtlichkeit im Schicksal des Einzelnen. In: KOSSLER, M.; BIRNBACHER, D.; BAUM, G. (Org.). Schopenhauer-Jahrbuch -Die Entdeckung des Unbewussten. Würzburg: Verlag Königshausen \& Neumann GmbH. Vol. 86. 2005. P. $179-195$.

ASSOUN, P-L. Freud: a Filosofia e os Filósofos. Trad.: Hilton Japiassu. Rio de Janeiro: Francisco Alves, 1978.

BERNHARD, W.. Schopenhauer und die moderne Charakterologie. In: SchopenhauerJabrbuch, Vol. 44, 1963.

BRUN, R.. Über Freuds Hypothese vom Todestrieb. In: Psyche, Vol. 7, 1953.

CLEGG, J.. Freud and the Issue of Pessimism. In: Schopenhauer-Jahrbuch, Vol. 61, 1980.

\footnotetext{
53 Freud reconheceu ao "eu" uma função primariamente libidinosa, e falou do "eu" como sendo um reservatório da libido, a partir do qual vinculações posteriores a objetos seriam enviadas (Cf. FREUD, Zur Einfübrung in den Narzissmus, p. 137-170).

54 Pelo menos mirado sobre o pano de fundo do entendimento filosófico de Freud.

55 Pelos preciosos estímulos a esse trabalho, agradeço amavelmente a R. Ferber.
} 
DIMITROV, C. T. A. Schopenhauer und S. Freud. In: Zeitschrift für Psychosomatische Medizin und Psychoanalyse, Vol. 17. 1971.

ELLENBERGER, H. F.. Die Entdeckung des Unbewußten, Zürich: Diogenes. 1985.

ELLENBERGER, H. F.. Das menschliche Schicksal als wissenschaftliches Problem. In: Psyche, Vol. 4, 1951.

FEUERBACH, L.. Gedanken über Tod und Unsterblichkeit aus den Papieren eines Denkers, nebst einem Anhang theologisch-satirischer Xenien, 1830.

FREUD, S.. Além do princípio do prazer. In: FREUD, S.. Obras Completas. Trad. e org.: P. C. de Souza. São Paulo: Companhia das Letras. 2010. Vol. 14.

FREUD, S.. Gesammelten Werke, chronologisch geordnet. 18 Vol. e um volume suplementar não numerado. In: FREUD, A. (Org.). Volumes 1-17, London: Imago Publishing, Co., 1940-1952. Vol. 18, Frankfurt/M.: Fischer, 1968. Nachtragsband, Frankfurt/M.: Fischer, 1987.

FREUD, S.. Jenseits des Lustprinzips. In: FREUD, S.. Gesammelten Werke, chronologisch geordnet. London: Imago Publishing, Co. Volume 13, 1940-1952.

FREUD, S.. Nachwort zur „Frage der Laienanalyse”. In: FREUD, S.. Gesammelten Werke, chronologisch geordnet. London: Imago Publishing, Co. Volume 14, 1940-1952.

FREUD, S.. Zur Einführung in den Narzissmus. In: FREUD, S.. Gesammelten Werke, chronologisch geordnet. London: Imago Publishing, Co. Volume 10.

FREUD, S.. Neue Folge der Vorlesungen zur Einführung in die Psychoanalyse. In: FREUD, S.. Gesammelten Werke, chronologisch geordnet. London: Imago Publishing, Co. Volume 15.

FREUD, S.. ABRAHAM, K.. Briefe 1907-1926. In: VON HILDA, C.. FREUD, E. L. (Org.). Frankfurt: S. Fischer, 1965.

FREUD, S.. Projeto para uma psicologia científica. In: FREUD, S.. Obra Completa. Edição Standard Brasileira. Tradução: J. Salomão. Rio de Janeiro: Imago, 1996. Vol. 1.

GAY, P.. Frend, eine Biographie für unsere Zeit. Frankfurt/M: Fischer. 1989.

GARDNER, S.. Schopenhauer Will and the Unconscious. In: JANAWAY, C. (Org.). The Cambridge Companion To Schopenhauer. Cambridge: Cambridge University Press, 1999.

GERMER, G. M.. Freud na Proximidade da 'Escola de Schopenhauer'. In: CARPARELli, M.. GIORDANO, F.. APPOLONIO, S.. Per mari inesplorati - Studi in Onore di Domenico M. Fazio. Lecce: Pensa Multimedia. 2017.

GIACOIA JR., O.. Além do princípio do prazer: um dualismo incontornável. Rio de Janeiro: Civilização Brasileira, 2008. 
GÖDDE, G.. Schopenhauer als Vordenker der Freudschen Metapsychologie. In: Psyche, Vol. 45. 1991.

GÖDDE, G.. Schopenhauers Entdeckung der Psychologie des Unbewussten. In: KOSSLER, M., BIRNBACHER, D., BAUM, G. (Org.). Schopenhauer-Jahrbuch-Die Entdeckung des Unbewussten. Würzburg: Königshausen und Neumann GmbH, 2005. Vol. 86. P. 15 - 36.

GRANJEL, L. S.. Schopenhauer y Freud, in: Actas Luso-Espanolas de Neurologiaj Psiquiatria, Vol. 9, 1950.

HANNS, L. A.. Dicionário Comentado do Alemão de Freud. Rio de Janeiro: Imago, 1996.

HORKHEIMER, M.. Das Schlimme erwarten und doch das Gute tun (Gespräch mit Gerhard Rein, 1972). In: SCHMIDT, A.. NOERR G, S. (Org.). Gesammelte Schriften. Frankfurt: Fisher, 1985, vol. 7.

HÜBSCHER, A.. Denker gegen den Strom, Bonn: Bouvier, 1982.

JONES, E.. Vida y Obra de Sigmund Freud. Trad.: M. Carlisky e J. Tembleque. Barcelona: Ed. Anagrama, Vol. 1, 1970.

JONES, E.. Sigmund Freud, Life and Work. London: Hogarth, Vol. 3. 1957.

KAISER-EL-SAFTI, M.. Der Nachdenker. Die Entstehung der Metapsychologie Freuds in ibrer Abhängigkeit von Schopenhauer und Nietzsche, Bonn: Bouvier, 1987.

LÜTKEHAUS, L.. Schopenhauers und Freuds „Dritte Kränkung“: Eine Verdrängungsgeschichte?. In: MALTER, R. (Org.). Schopenhauer-Jahrbuch. Frankfurt: Verlag Waldemar Kramer, 1987.

MERTON, R.. The Ambivalence of Scientists, in: Sociological Ambivalence and other Essays. New York: Free Press, 1976.

MOCKRAUER, F.. Schopenhauers Stellung in der Philosophie der Gegenwart. In: MOCKRAUER, F. (Org.). Zwölftes Jabrbuch der Schopenhanergesellschaft für die Jahre 1923_1925. Heidelberg: Carl Winter's Universitätsbuchhandlung.

MONZANI, L. R.. Freud: O movimento de um Pensamento. Campinas: Editora da Unicamp, 1999.

MORIN, E.. L'bomme et la mort dans l'bistoire. Paris: Seuil, 1962.

NICOLINO, F.. Indagini su Freud e sulla Psicoanalisi. Napoli: Liguori. 1981.

NITZSCHKE, B.. Die reale Innenwelt, Anmerkungen zur psychischen Realität bei Freud und Schopenhauer. München: Kindler, 1978.

NITZSCHKE, B.. Zur Herkunft des Es (II). In: Psyche, Vol. 39, 1985. 
RANSOM, J. C.. Freud and Literature. In: KIELL, N (Org.). Freud without Hindsight, Reviews of his works (1893 - 1939). Madison GT: International Universities Press. 1987.

RATTNER, J.. Klassiker der Tiefenpsychologie. München: Psychologie Verlags Union. 1990.

SANER, H.. Das Sein zum Tode aus philosophischer Sicht, in: Die Psychologie des 20. Jahrbunderts, Band XV: Transzendenz, Imagination und Kreativität, Zürich: Kindler. 1979.

SCHOPENHAUER, A.. Sämtliche Werke. In: HÜBSCHER, A. (Org.). 7 Volumes. Mannheim: Brockhaus, 1988.

SCHOPENHAUER, A.. Der Handschriftliche Nachlaß. In: HÜBSCHER, A. (Org.). 5 Volumes. Frankfurt/M.: Verlag Waldemar Kramer.

SEIDMANN, P.. Religiöse und philosophische Wurzeln der Psychotherapie, Hinweise und Erwägungen. In: Die Psychologie des 20. Jabrhunderts, Band XV: Transzendenz, Imagination und Kreativität. Zürich: Kindler, 1979.

SEIFERT, F.. Tiefenpsychologie, Düsseldorf / Köln: Diedrichs. 1955.

TAVARES, P. H.. As novas traduções de Freud feitas diretamente do alemão: estilo e terminologia. In: TradTerm, São Paulo, Vol. 19, 2012.

SOUZA, P.C. As Palavras de Frend - O Vocabulário Frendiano e suas Versões. São Paulo: Ática, 1999.

SOUZA, P.C. Esta edição. In: FREUD, S.. Obras Completas. Trad. e org.: P. C. de Souza. São Paulo: Companhia das Letras. 2010. Vol. 14. P. 9 - 12.

SULLOWAY, F.. Freud, Biologist of the Mind. New York: Basic Books, 1983.

WAGNER, G. F.. Enzylklopädisches Register zu Schopenhauers Werken. Stuttgart-Bad Canstatt: Frommann, 1982.

YOUNG, C.; BROOK, A.. Schopenhauer and Freud. In: Internation Journal of Psychoanalysis, N. 75, 1994.

ZENTNER, M. R.. Der Wahnsinn als „Lethe unerträglicher Leiden“, Addenda zu Schopenhauers Antizipation der Freudschen Verdrängungstheorie. In: SchopenhauerJahrbuch, Vol. 75, Würzburg: Königshausen \& Neumann, 1994.

ZENTNER, M. R.. Der Selbstmord als Antwort auf das Leid bei Schopenhauer. In: Freiburger Zeitschrift für Philosophie und Theologie, Vol. 35, N. 3, 1988. 
179 | Apresentação e tradução de "O objetivo de toda a vida é a morte" - Schopenhauer e o instinto de morte de Freud, de Marcel Zentner

Recebido: 10/11/18

Received: 11/10/18

Aprovado: 20/11/18

Approved: 11/20/18 